\title{
Discurso (*)
}

\section{Fernando Emydio da Silva}

Vem escrita em latim a mensagem que vos entreguei do reitor da Universidade de Lisboa. Aqui está uma velha praxe que, mesmo no intercâmbio luso brasileiro, fica bem. O latim é a língua universitária por excelência. Precisão, agilidade, clareza, recorte, fundo: nunca o humano encontrou expressão verbal mais perfeita e mais feliz. Na Sorbonne, por exemplo, já ia alto o Renascimento, ainda se falava em latim. Quando Rollin escreveu em francês o seu famoso tratado, D'Aguesseau dispara-lhe logo este louvor algum tanto imprevisto: "Monsieur, vous écrivez le français comme si c'était votre langue naturelle"

Valha ao menos, como símbolo, esta reminiscência altiva.

Porque, menos sabedor, terei de falar-vos na minha língua natural.

Felizmente que esta tambem tem os seus pergaminhos de velha nobreza - e está em sua casa no Brasil.

Não sou dos que dizem o mundo perdido.

Ele continuará sempre, afinal, na sua rota. Mas sou dos que dizem o mundo doente.

Há, por exemplo, neste momento, um estranho sintoma.

(*) Proferido ao entregar, à Faculdade de Direito da Universidade de São Paulo, a mensagem da Universidade de Lisboa, na sessão solene de recepção, realizada, em 27 de novembro de 1939 , na sala "João Mendes" 
O mundo que não sabia estar em paz - parece que tambem não sabe estar em guerra.

Em paz - fazia já a guerra.

Em guerra - ainda não saíu inteiramente da paz.

Depois da guerra - o dilúvio? E daí, no instante supremo, a indecisão derradeira?

E' natural.

Mas os que o deus maligno quer perder — dementa-os primeiro.

Foi muito antes da guerra que se perdeu a fórmula da paz.

Vou usar de linguagem direta e vou direito até o fundo.

Porque é da Universidade que se torna sobretudo visivel o desconcerto do mundo.

Haverá, realmente, duas verdades, como no teatro de Pirandello?

Uma que se ensina, cá dentro?

Outra que se pratica lá fóra?

Em contradição plenária, quasi sempre, as duas, entre si?

Eu creio que chegado ao cimo só ha uma verdade.

$\mathrm{E}$ quando cá de baixo se lhe perdeu a vista - ha sempre uma conta de erros para pagar.

Porque a crise atual é, acima de tudo, uma crise de princípios.

Dí-lo o universitário impenitente que me orgulho de ser.

Mas dí-lo tambem o meu sentido das realidades.

Deixemos o campo moral.

Porque aí bastaria uma só regra a considerar. O respeito da palavra dada.

Encubram com os nomes que quiserem os meros subterfúgios com que a subvertam. 
Sem o respeito da palavra dada, não sei de laço duradouro que persista entre os homens.

E' o raciocínio de uma criança.

Mal vai quando se pratica ao invez da verdade evidente.

Mas passemos ao estrito campo da economia e das finanças, minha lavra de ação profissional.

Aí o mal vem todo com efeito de que se perdeu lá fóra o culto dos princípios ensinados aquí dentro.

E é sempre a mesma coisa lamentavel.

A mesma coisa de uma simplicidade infantil.

Aquilo que todos vêem - que é assim. e, apesar de tudo, ninguem faz.

Comecemos pela economia.

Os que apredemos economia política antes da guerra (antes da outra guerra) já haviamos aprendido todos os argumentos de doutrina e de fato para condenar a inflação. Havia o exemplo retumbante da Revolução Francesa. Havia, em Portugal, o exemplo caseiro da crise do papel moeda com que abriu o século XIX. Havia, em Portugal ainda, o próprio exemplo contemporâneo, do século $\mathrm{XX}$ que começava para nós sob o terror salutar de uma inflação imaginária. Pois bem. Mais uma vez experiência não serviu a ninguem. E nós nem tivemos a desculpa da guerra. Fomos para a inflação, depois da guerra. Resultado. Em certo momento nem foi já o volume das notas que deu a medida da desvalorização; foi o medo das notas que estavam para ser estampadas. Mas prossigamos. Todos sabiam que só atacando as raizes do mal este cessaria. O que se fez? Quando o pânico pareceu ameaçar os alicerces do país, fezse o mero camouflage da inflação: cobertura do "deficit" orçamental, aliás agravado, com emissões massiças de bilhetes do Tesouro e sangrias repetidas à Caixa Geral dos Deputados. Resultado? No fim do caminho só havia um. Quando o pânico, de volta, exigisse, nos "guichets" do Estado o reembôlso dos credtos à vista ou vencidos - o dile- 
ma que, de novo viria, entre a inflação e a falência. E enquanto não chegasse (salvamo-nos, de resto, a tempo) o preço do adiamento que ficava visível na dívida flutuante. Chegamos a pagar $11 \%$ de juro por dinheiro a 6 meses. Ahi têm V. Exas. um exemplo, em que até ha uma taxa oficial para marcar o custo do êrro.

Um segundo caso é por igual edificante. Nunca foram tão várias, tão rápidas e tão fáceis as possibilidades de comunicação entre os homens. Pois bem. Nunca os países cercados por outras tantas muralhas da China estiveram mais ciosamente fechados uns aos outros e à interpenetração dos seus preços como das suas idéias. Porque a naturera mesma dava as suas indicações de vocação incontroversa. Bastava, parece, que produzir e permutar, com a limitação dos direitos do fisco, a restrição operada a tempo contra o risco de superabundância e uma proteção razoavel a actividades não contra-indicadas. Quer dizer: não um liberalismo puro, mas corrigido. $O$ pendor natural seria assim o da vida barata, único meio de democratizar a fartura e a fortuna entre os homens. Pois bem. Em toda a parte, com nomes e práticas diversas, se organizou a vida cara. Resultado. A crescente miséria no mundo. Miséria em pobreza de bens. Miséria em pobreza de idéias. Chegou-se a desafiar o Destino: queimadas sacrílegas de trigo, quando se morria à volta de fome. Porque o arsenal de guerra do nacionalismo econômico, se quís formar a autarquia, só está assestado a combater a miragem: ultra-protecionismo, contingentes, fiscalização de câmbios, interdição à saída do dinheiro. E' que uma economia pautada pelo risco de guerra e na mera consideração desse risco, só tem uma saída : sair para fóra dos seus próprios moldes.

Tomemos ainda, na vizinhança imediata do alegado, um outro exemplo, com as suas duas facetas e que lhes trago de Portugal.

Tempos houve em que se multiplicaram a êsmo as leis de proibição cambial. As fronteiras ficaram, nesse tempo, sempre abertas à fuga invisivel mas segura do dinheiro. 
Caíram todas essas barreiras e estabeleceu-se a plena liberdade de câmbios. Os capitais têm afluido em massa ao país.

Claro, o saneamento financeiro havia sido feito no intervalo.

Mas atendeu-se tambem ao seguinte: não basta que a porta esteja aberta para o dinheiro entrar.

E' preciso que continue aberta quando queira sair.

Quando não. não entra.

Aí está outra coisa, de uma simplicidade infinita. Mas que quasi todos esquecem, regularmente, tambem.

Economia dirigida?

Ocorre-me sempre a pergunta já hoje sacramental: Quem serão, a cada momento, os seus diretores? Já o disse na Academia Brasileira. E' ensinando, é prevenindo, é controlando, é amparando, é limitando, é corrigindo que se moderam os excessos e suprem as insuficiências da pública economia. E não é quem muitas vezes não soube nem lecionar, nem advertir, nem fiscalizar, nem socorrer, nem proíbir, nem emendar - tarefa mais simples - que súbito, tocado não sei por que espírito adivinho, em tudo póde com proveito intervir, resolver e dispôr.

Dizem em Portugal que o Diabo sai uma vez por ano dos infernos e anda uma hora à sôlta pela terra. E' no dia de $\mathrm{S}$. Bartolomeu e das 12 ás 13 horas: o que não sei é se regula para o horário o meridiano de Greenwich. Pois bem. Acho que uma hora deve chegar à sua esperteza lendária para conservar o sorriso satânico.

Passemos da economia ás finanças.

Mas não passemos agora de Portugal. Portugal of erece, neste particular, a prova e a contraprova quanto à observância dos princípios que se ensinam correntemente na Faculdade. 
Primeiro a contraprova, pela sua não observância.

Durou um século, no estado crônico.

Durou dez anos, depois da guerra, no estado agudo. Formámos assim, no capítulo, o que posso chamar o perfeito manual das más finanças.

E por que?

Porque não equilibrámos o orçamento.

Porque não revimos as despesas.

Porque buscámos impostos imperantes sobre o desconhecimento da matéria coletavel.

Porque desarticulámos todo o mecanismo da divida, de maneira a esta perder os seus movimentos naturais.

Porque não soubemos organizar a contabilidade do Estado.

Quer dizer: porque nada fizemos do que se ensina neste logar.

Em 1928, no mais agudo dessa crise, uma súbita transformação radical.

Do perfeito manual das más finanças, passámos à iluminura de um tratado clássico.

E por que? por sua vez?

Porque se obteve o seguinte:

Em vez do "deficit" crônico, doze anos de equilíbrio nas contas públicas.

Em vez de um orçamento ilegivel, um orçamento que todos sabem ler.

Em vez de previsões orçamentais indefensáveis, um texto cumprido a rigor na sua letra e no seu equilíbrio.

Em vez da anarquia e abandono dos serviços, uma ciudadosa revisão das despesas.

Em vez de impostos inofensivos ou atrabiliários, o sentido das realidades tributárias e, sem alterar a paz civil, uma colheita satisfatória nos rendimentos fiscais.

Em vez de uma dívida anarquizada e inoperante, o crédito público inteiramente refeito. 
Em vez de uma dívida flutuante patológica, o volante do tesouro assegurado pela acumulação dos saldos orçamentais.

Em, vez de taxas de juro usurário, emprestimos a $33 / 4$ e $31 / 2$.

Quere dizer:

Em vez de não fazer o que se ensina nas aulas de finanças, passou a fazer-se o que nelas se ensina.

Resultado?

As finanças clássicas deram-nos finanças sãs. As finanças sãs deram-nos a confiança renascida. A confiança renascida irradiou.

Equilibraram-se os orçamentos das colônias.

Estabilizou-se a moeda.

Equilibrou-se a balança econômica.

Terminou, praticamente, o desemprêgo.

Inaugurou-se a política do dinheiro barato. A formula de Salazar, professor de Finanças da Faculdade de Direito de Coimbra, veiu em linha reta das suas lições.

Interessa-me ainda, neste fortúito e para mim inesquecivel encontro, apelar como português para a vossa autoridade. Focar uma derradeira questão.

A questão luso-brasileira por excelência.

A defesa da lingua comum.

Começo por focar aqui um interesse político fundamental.

A defesa da lingua, primeiro suporte espiritual da nação, tem hoje, na verdade, e por motivos óbvios, um acrescido interesse. Não faltam inesperadas ofensivas de toda a ordem para dissociar os povos ou apresentá-los como tal. Urge mais do que nunca, dentro de fronteiras, que se forme um bloco só. Aí está, sem disparatados excessos, mas com excepcional firmeza, onde o nacionalismo deve operar com vigilância incessante. Defender o idioma é de- 
fender a independência pátria. Aí está, precisamente, tambem, o que nunca poderá separar-nos.

Vale, de resto, a pena de ser defendido, se á mera creação do rigor e da beleza literária me reporto o idioma que em Quinhentos já teve côr e agilidade bastantes para nele se escrever o seu poema definitivo: que bastou à opulencia de Vieira, à cintilação de Francisco Manuel, ao recorte sereno de Bernardes, à limpidez de Garrett, à profundidade de Antero, à elegancia e transparencia do EçA, à imensidade de Camilo e, transposto o oceano, aos lampejos do gênio de Rui Barbosa e à arte perfeita de escrever que dá a Machado de Assis um logar junto de Queiroz, de Renan ou de France.

Mas ainda aqui é preciso apelar, com urgência, para a soberania das regras.

E em todos os seus gráus e em todas as suas espécies é preciso que o Ensino as defenda.

Dois inimigos da clara linguagem eu entendo que devemos denunciar e combater impiedosamente.

A difusão.

E a ênfase.

E' que esses defeitos ultrapassam o campo filológico e invadem até a zona moral.

A difusão. Ha no soberbo reportório das nossas anedotas colonias esta espécie característica com três personagens vivos: o réu indígena que já discorreu em seu linguajar mais de uma hora; o juiz impaciente que o interrompe para perguntar ao intérprete o que foi dito; o intérprete que placidamente responde: por enquanto não disse nada; está falando... Lembra-me o fêcho lapidar da missiva de Voltaire: "Peço desculpa desta carta ir tão comprida; falta-me o tempo para a fazer mais curta"

A ênfase. Peior talvez ainda do que a difusão. Esta ainda póde ter desculpa em fortúitas necessidades de dissimulação urgente. quer dizer, quando não ha tempo para inventar melhor. A ênfase, essa nunca póde ter uma atenu- 
ante. E' o pecado mortal da simples vaidade humana que se viu em espêlho deformante.

A perfeição da palavra falada ou escrita ha-de estar sempre nas suas virtudes clássicas, de que o gênio francês é hoje o seu expoente mais representativo. Concisão, clareza, lógica. A elegância na sobriedade. A riqueza no rigor do conceito. Cada palavra com o seu toque próprio. Cada oração em seu seguimento ordenado. Sem excluir a personalidade, o abandono, a abundância; sem reclamar para a razão didática o que é tambem logar do sentimento e do capricho - a língua fez-se, no entanto, para ser entendida com comodidade, rapidez e plenitude.

Eu não reclamo a linguagem telegráfica como modelo de beleza filológica. Mas ha contra a prolixidade um legítimo direito de defesa da impaciência humana.

Reconheço, por minha parte, esse vosso legítimo direito. E vou acabar.

Mas ao fazê-lo eu quero agradecer a vossa hospitalidade carinhosa e fraterna e as vossas palavras, onde inflação tem por derimente o signo da Amizade.

Sei o que representa S. Paulo na história, na economia e na virtude do Brasil.

Sei o que representa a vossa Faculdade de Direito como lustre e honra da cidade.

Inclino-me respeitosamente perante os seus mestres.

Saudo com ternura os seus estudantes. Possam eles ser amanhã, na paz ininterrompida, os obreiros do Brasil maior: da Pátria sempre mais feliz; seguidores da lição aprendida nesta casa pelo ensino e pelo exemplo. Orgulho do Brasil que será sempre tambem orgulho nosso.

Possam tambem entre as nossas duas Faculdades estreitar-se ainda os laços que as reunem.

Lembro-me com viva saudade as lições que fez em Lisboa o vosso ínclito Waldemar Ferreira. 
Continua hoje, em muito menos bem, essa tradição necessária. Mas a vossa generosidade já fez esquecer esse muito menos bem, inerente ao desvalioso missionário de Lisboa, para só ver o que no seu coração ha de fé transbordante na grandeza do destino brasileiro, na afeição inseparável de nossas pátrias unidas e, se me é lícito falar de pátrias mais pequenas (e não menos amadas), nos laços que juntem melhor as nossas duas Faculdades. 